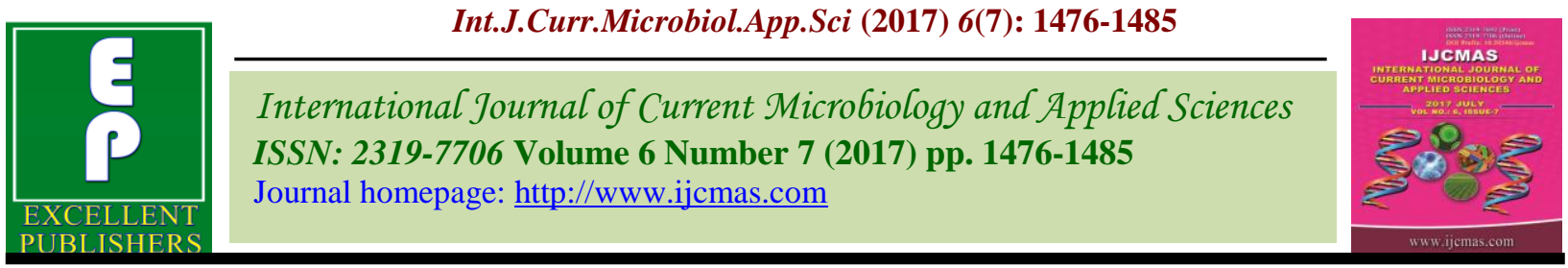

Review Article

https://doi.org/10.20546/ijcmas.2017.607.176

\title{
Ecological Engineering for Pest Management in Agro Ecosystem-A Review
}

\author{
Muneer Ahmad* and S.S. Pathania \\ Division of Entomology, Sher-e-Kashmir University of Agricultural Sciences and Technology \\ Shalimar Srinagar, Kashmir, J\&K, India \\ *Corresponding author
}

\begin{tabular}{|c|c|}
\hline & A B S T R A C T \\
\hline & $\begin{array}{l}\text { Plants are not capable of running away from their enemies, i.e., the herbivores that may eat } \\
\text { them. However, under certain circumstances, plants can rely on the natural enemies of } \\
\text { insect herbivores for protection. These natural enemies include other insects that are } \\
\text { predators and parasitoids. Habitat manipulation, which is also referred to as "Ecological }\end{array}$ \\
\hline Keywords & $\begin{array}{l}\text { Engineering", focuses on reducing mortality of natural enemies, providing the } \\
\text { supplementary resources and manipulating host plant attributes for the benefit of natural }\end{array}$ \\
\hline $\begin{array}{l}\text { Ecological, } \\
\text { Pest, } \\
\text { Management } \\
\text { and Habitat. }\end{array}$ & $\begin{array}{l}\text { bio-agents. This can be achieved by enhancing the plant diversity and by providing } \\
\text { adequate refugia in the agro-ecosystem. In this article we review the use of natural enemies } \\
\text { in crop pest management and describe } m \text { research needed to better meet information needs } \\
\text { for practical applications. Endemic natural enemies (predators and parasites) offer a }\end{array}$ \\
\hline Article Info & potential but understudied approach to controlling insect pests in agricultural systems. \\
\hline $\begin{array}{l}\text { Accepted: } \\
19 \text { June } 2017 \\
\text { Available Online: } \\
10 \text { July } 2017\end{array}$ & $\begin{array}{l}\text { appeal as a method to reduce the need for pesticides while maintaining agricultural } \\
\text { profitability. Habitat for sustaining populations of natural enemies occurs primarily at field } \\
\text { edges where crops and edge vegetation meet. Conservation and enhancement of natural } \\
\text { enemies might include manipulation of plant species and plant arrangement, particularly at }\end{array}$ \\
\hline & $\begin{array}{l}\text { these edges; and consideration of optimum field sizes, number of edges, and management } \\
\text { practices in and near edges. Blending the benefits of agricultural and forestry (windbreak) } \\
\text { systems is one promising approach to field edge management that has additional benefits } \\
\text { of wind protection. }\end{array}$ \\
\hline
\end{tabular}

\section{Introduction}

The management of nature is ecological engineering (ODUM 1971)

This review is essentially about the management of arthropod pests, though at least some of the principles described will have relevance to other pests, weeds and pathogens. Over recent decades, integrated pest management (IPM) - the combined use of multiple pest-control methods, informed by monitoring of pest densities - has emerged as the dominant paradigm. Each of the specific methodological approaches used in IPM (mechanical, physical and cultural control; host plant resistance; biological control etc; Figure 1) has tended to become a specialised area of research with sometimes only limited communication between researchers across areas. Even sub-areas, such as the four forms of biological control (conservation, classical, inoculation and inundation) recognized by Eilenberg et al., (2001) (Figure 1), have 
tended to become the domain of specialists. This has led to calls for greater cooperation and exchange of ideas between different subdisciplines. In the case of biological control, for example, Gurr and Wratten (1999) proposed the concept of 'integrated biological control', which uses conservation biological control techniques to support classical, inoculation and inundation biological control.

Conservation biological control (CBC) has been defined as 'modification of the environment or existing practices to protect and enhance specific natural enemies of other organisms to reduce the effect of pests' (Eilenberg et al., 2001). In practice, CBC is affected by either (1) reducing the pesticideinduced mortality of natural enemies through better targeting in time and space, reducing rates of application or using compounds with a narrower spectrum efficacy, or (2) by habitat manipulation to improve natural enemy fitness and effectiveness.

The second approach often involves increasing the species diversity and structural complexity of agro ecosystems. In the context of $\mathrm{CBC}$, habitat manipulation aims to provide natural enemies with resources such as nectar (Baggen and Gurr, 1998), pollen (Hickman and Wratten ,1996), physical refugia (Halaji et al., 2000), alternative prey (Abou-Awad, 1998), alternative hosts (Viggiani, 2003) and lekking sites (Sutherland et al., 2001). Habitat manipulation approaches, such as those pictured in figure 1, provide these resources and operate to reduce pest densities via an enhancement of natural enemies. For example, 'beetle banks' (Figure 1) are raised earth ridges that typically run through the centre of arable fields and are sown to perennial tussock-forming grasses. During the winter, far higher densities of predatory arthropods shelter on the well-drained, insulated sites than in the open field. In the spring, beetles and other natural enemies emerge from the beetle bank to colonise the growing crop and prevent pest aphid outbreaks (Thomas et al., 1991).When herbivores (the second trophic level) are suppressed by natural enemies (third trophic level) in this manner, control is said to be 'top-down'. Root (1973) referred to pest suppression resulting from this effect as supporting the 'enemies' hypotheses. Importantly, however, within-crop habitat manipulation strategies such as cover crops and green mulches (components of the first trophic level, as is the crop) can also act on pests directly, providing 'bottom-up' control. Root (1973) termed pest suppression resulting from such non-natural enemy effects as the 'resource concentration hypothesis', reflecting the fact that the resource (crop) was effectively 'diluted' by cues from other plant species. These mechanisms are explored in detail in chapter 3, 'The agro ecological bases of ecological engineering for pest management', by Nicholls and Altieri. Though considerable attention has been devoted to testing the relative importance of bottom-up and top-down effects, they are not mutually exclusive and in many systems both are likely to operate (Gurr et al., 1998). Thus habitat manipulation, though it makes a major contribution to $\mathrm{CBC}$, includes a wider series of approaches that may operate independently of natural enemies (Figure 1) and, as discussed below, constitute a form of ecological engineering. Examples of ecological engineering for pest management that operate largely by top-down effects are detailed by Pfiffner and Wyss in chapter 11, 'Use of sown wildflower strips'. Natural enemies use such strips for resources such as nectar and pollen in ways explored by Jervis et al., (Ch. 5, 'Use of behavioural and lifehistory studies'). The push-pull and intercropping approaches described in the two chapters by Khan and Pickett (ch. 10) and Mensah and Sequeira (ch. 12) employ topdown effects, but the operation of bottom-up effects is also clearly evident. 


\section{Ecological engineering}

Odum (1962) was among the first to use the term 'ecological engineering', which was viewed as 'environmental manipulation by man using small amounts of supplementary energy to control systems in which the main energy drives are still coming from natural sources'. In more recent years, Mitsch and Jorgensen (1989) have defined ecological engineering as 'the design of human society with its natural environment for the benefit of both'. Among, the characteristics of this form of engineering are the use of quantitative approaches and ecological theory as well as the view of humans as part of, rather than apart from, nature. Ecological engineering is a conscious human activity and should not be confused with the more recently developed term 'ecosystem engineering'. This refers to the way in which other species shape habitats via their intrinsic biology rather than by conscious design. For example, termites alter the structural characteristic of soils (Dangerfield et al., 1998), and such ecosystem engineers thereby moderate the availability of resources to other organisms (Thomas et al., 1999). Recently, Parrott (2002) has discussed the ecological engineering field as having evolved to incorporate a growing number of practitioners whose endeavour is the 'design, operation management and repair of sustainable living systems in a manner consistent with ecological principles, for the benefit of both human society and the natural environment'. Possibly, however, the most elegant definition of ecological engineering comes from Chinese approaches where a long history of complex land use systems was, in the closing decades of the 20th century, formalised into a 'design with nature' philosophy (Ma, 1985). The existence of the well-established periodical Ecological Engineering: The Journal of Eco Technology is evidence of the level of activity in this research field. This title reflects the synonym for ecological engineering, 'eco technology'. Various disciplines are allied to ecological engineering: restoration ecology, sustainable agro ecology, habitat reconstruction, ecosystem rehabilitation, river and wetland restoration and reclamation ecology (Mitsch, 1991). These sub-sets indicate the range of areas in which ecological engineering has been applied, including the restoration of wetlands, treatment and utilisation of wastewater, integrated fish culture systems and mining technology (Mitsch and Jorgensen, 1989) as well as wildlife conservation (Morris et al., 1994).

Adapting and designing the agricultural system to the environment of the region (e.g. choice of appropriate crop species and cultivars);

Optimizing the use of biological resources in the agro ecosystem (e.g. the use of biological control);

Developing strategies that induce minimal changes to the natural ecosystem to protect the environment and minimise use of nonrenewable resources (e.g. appropriate fertiliser formulations and application patterns).

Reflecting the utility of the ecological engineering paradigm to agriculture, the term 'agro ecological engineering' has developed currency (e.g. Hengsdijk and van Ittersum, 2003) and this has been viewed explicitly as a way towards sustainable agriculture in China, where it is said to be thriving (Liu and Fu, 2000). These authors hold that agro ecological engineering produce agricultural systems with multi-components and multi-storey vegetation giving higher vegetative cover than is typical of monocultures. As explored by many authors in the present volume, vegetational diversity plays a central role in habitat 
manipulation. It could be argued that all pest management approaches (Figure 1) are forms of ecological engineering, irrespective of whether they act on the physical environment (e.g. via tillage), chemical environment (e.g. via pesticide use) or biotic environment (e.g. via the use of novel crop varieties). It is, however, the use of cultural techniques to effect habitat manipulation and enhance biological control (Figure 1) that most readily fit the philosophy of ecological engineering. These cultural techniques typically:

Involve relatively low inputs of energy or materials;

Rely on natural processes (e.g. natural enemies or the response of herbivores to vegetation diversity);

Have developed to be consistent with ecological principles;

Are refined by applied ecological experimentation;

Contribute to knowledge of theoretical and applied ecology (Figure 1).

\section{The development of habitat manipulation}

Contemporary habitat manipulation has its genesis in practices that have been used to promote generalist predators in agricultural systems for centuries (Sweetman, 1958). An example of an early habitat manipulation technique, used by Chinese farmers for over 2000 years and still in use today, is the use of straw shelters to provide temporary spider refugia and overwintering sites during cyclic farming disturbances (Dong and $\mathrm{Xu}, 1984$ ). Another technique, developed in Burma in the 1770s, used connecting bamboo canes between citrus trees to enable predatory ants to move between the trees to control caterpillar pests (van Emden, 1989).

\section{Habitat manipulation approaches}

\section{Top down control}

Here herbivores (second trophic level) are suppressed by the natural bio-agents (third trophic level) and this type of approach is seen in 'Augmentive biological control'.

\section{Bottom up control}

In this approach, manipulation within crop, such as green mulches and cover crop (first trophic level) will act on pests directly. This type of approach is seen in habitat manipulation of 'Conservation biological control.

\section{Possible ways to enhance natural diversity}

\section{Structural and cultural diversity}

Trees and other tall vegetation can provide the vertical structure needed by spiders and birds. Flowering shrubs, herbs and annual and perennial forbs can provide for parasitic ichneumonids and syrphids that feed on flower, nectar and pollen. The syrphids are predators of aphids (Leius, 1967) and are more abundant in areas of high floral diversity and abundance (Ruppert and Moltan, 1991). Aphids that feed on goldenrod can be used as alternative prey for ladybird beetles (Coccinellidae) when population of their primary prey is low (Altieri and Whitcomb, 1979).

\section{Overwintering sites}

Windbreaks can be used by arthropod predators as overwintering sites if appropriate vegetation is available. In South Carolina, certain species of coccinellids that feed on insect pests of field and orchard crops overwinter at field edges in herbaceous vegetation, grass, and tree litter (Roach and 
Thomas, 1991). Woody field edges can provide habitat for birds or small mammals' that feed on insect pests during the winter (Black et al., 1970; Johnson and Beck, 1988).

\section{Cultural practices}

Cultural practices such as plowing, cultivating and harvesting can radically alter the abundance of predators such as spiders, birds, and small mammals. Clean cultivation of a field or around trees may increase crop survival but also can decrease survival of birds, small mammals, spiders, or carabids that use the vegetation for shelter. For example, raking hackberry leaves from lawns removes parasites of the hackberry nipplegall maker. Pachypsylla celtidismamma (Fletcher) (Homoptera: Psyllidae) an insect that overwinters in the leaf galls. In rural areas, the leaves are not removed and the parasites control the psyllids (W. Cranshaw, Colorado State University, personal communications). Likewise, crop stubble left in fields might contain overwintering parasitic wasps or may provide cover for predators such as birds, overwintering spiders, or beetles.

Fig. 1 The effects of agroecosystem management and associated cultural practices on the biodiversity of natural enemies and abundance of insect pests

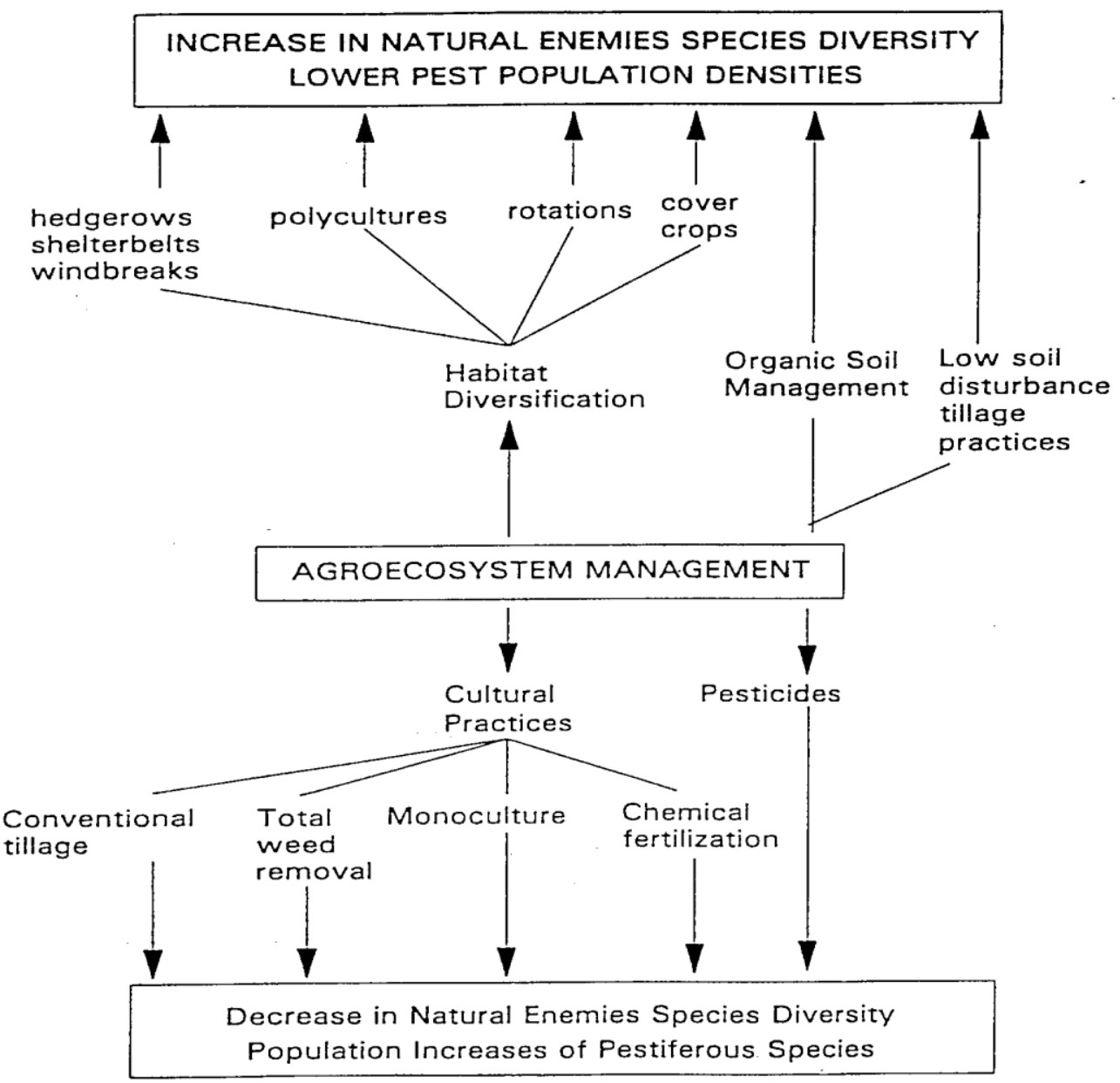




\section{Windbreak design}

Windbreak design is another method of manipulating natural enemy abundance, and diversity. In North Dakota, carabids and staphylinids (Coleoptera) that feed on crop pests were more abundant at the edge of multi-row wind breaks than in the interior of the windbreak (Katayama, 1980). In singlerow elm windbreaks, most of the windbreak is edge; thus, carabid and staphylinid abundance should be relatively constant across the windbreak (Frye et al., 1988).

Conversely, insectivorous birds establish large territories and prefer larger, wider windbreaks. Other species may benefit from curved or undulating windbreak designs that provide greater amounts of edge and less exposure when feeding in fields near the edge (PFRA, undated).

\section{Pesticides}

Although pesticides are the most frequently used method of controlling pests, most pesticides kill not only the target pest but many of its invertebrate natural enemies.

They also may adversely affect vertebrate natural enemies and other non-target organisms and, over time, most insect pests can develop resistance to a pesticide. Minimizing the use of pesticides, proper selection and application of pesticides when needed, and use of other integrated pest management techniques when possible are methods of reducing these adverse effects and conserving natural enemy abundance.

\section{Providing refugia}

Plants, which shelter the natural enemies during unfavourable periods like winter in high altitudes, dry seasons in tropical areas, are called so. Artificially created grasses sown

\section{Constraints and future prospects}

There is basic need to strengthen the research on defining the role of the tritrophic interactions, cultural practices and other practices in improving the efficiency of the natural enemies for important species of natural enemies used in India. Integration of the conservation and manipulation techniques in the IPM modules should be done and be tested for proper pest management practices for different crop pests. A concerted research effort between different disciplines such as Plant Breeders, Agronomist, Soil Scientists, and Chemists and Entomologists is necessary to develop viable technologies with consideration to the conserving of the natural enemies or increasing the efficiency of the natural enemies. Removing the extension gap between the researcher and the farmer is pivotal for the success of the conservation and manipulation techniques. Some of the farmers still believe in 'clean cultivation' by burning the residual crops, deep ploughing etc. as the right way of control without being aware of the damage caused to the natural enemies. Periodical training is necessary to educate the extension workers and farmers on biological control incorporating the conservation and manipulation methods. Most of the experiments especially on the use of semi chemicals were conducted in smaller area or in semi field conditions and thus make difficult to draw any conclusions. Studies should be conducted in larger areas so as to generate good amount of data on the use of the semi chemicals.

In conclusion, Habitat manipulation is another form of augmentation and conservation of natural enemies in which cropping system altered successfully to augment and enhance the effectiveness of the natural enemies. Adult parasitoids and predators significantly benefited from source of nectar and the protection provided by refuge (hedge rows, 
cover crops and weedy borders). Mixed planting increase the diversity of habitats and provide more effective shelter and alternative food source to predators and parasites.

\section{References}

Aalbersberg, Y.K.,Westhuizen, M.C. van der and Hewitt, P.H. (1989). Japanese radish as a reservoir for the natural enemies of the Russian wheat aphid Diuraphis noxia (Hemiptera: Aphididae). Phytophylactica 21 (3): 241-245.

Abou-Awad, B.A., El-Sherif, A.A. et al., (1998). Studies on development, longevity, fecundity and predation of Amblyseius olivi Nasr and Abou-Awad (Acari: Phytoseiidae) on various kinds of prey and diets. Zeitschrift fur Pflanzenkrankheiten und Pflanzenschutz 105 (5): 538-544.

Agriculture, Ecosystems and Environment 22/23: 301-335.

Altieri MA and Whitcomb WH (1979) the potential use of weeds in the manipulation of beneficial insects. Horticulture Science 14: 12-18.

Altieri, M.A. (1991). Increasing biodiversity to improve insect pest management in agro-ecosystems. In Biodiversity of Microorganisms and Invertebrates: Its Role in Sustainable Agriculture (D.L. Hawksworth, Ed.), pp. 165-182. CAB International, Wallingford.

Best LB (1983) Bird use of fencerows: implications of contemporary fencerow management practices. Wildlife Society Bulletin II: 333-347.

Best LB, Whitmore RC and Booth GM (1990) Use of cornfields by birds during the breeding season: the importance of edge habitat. American Midland Naturalist 123: 84-99.

Black ER, Jr, Davis I'M, Henderson CA and Douglas WA (1970) the role of birds in reducing overwintering populations of the southwestern corn borer, Diatraea grandiosella (Lepidoptera: Crambidae), in Mississippi. Annals of the Entomological Society of America 63: 701-706.

Brandle JR, Hintz DL and Sturrock JW (1988) Windbreak Technology. Elsevier Science Publishers, 598 pp.

Brandle JR, Johnson BB and Akeson T (1992) Field windbreaks: are they economical? Journal Production Agriculture 5: 392-398.

Bryan GG and Best LB (1991) Bird abundance and species richness in grassed waterways in Iowa rowcrop fields. American Midland Naturalist 126: $90-102$

Buckner CH and Turnock WJ (1965) Avian predation on the larch sawfly, Pristiphora erichsonii (Htg.) (Hymenoptera: Tcuthredinidac). Ecology 46: 223-236.

Bugg, R.L., Wackers, F.L., Brunsen, K.E., Dutcher, J.D. and Phatak, S.C. (1991). Cool-season cover crops relay intercropped with cantaloupe: influence on a generalist predator, Geocoris punctipes (Hemiptera: Lygaeidae). Journal of Economic Entomology 84 (2): 408-416.

Collins, K.L., Boatman, N.D.,Wilcox, A., Holland, J.M. and Chaney, K. (2002). Influence of beetle banks on cereal aphid predation in winter wheat. Agriculture, Ecosystems and Environment 93 (1-3): 337-350.

Collyer, E. and van Geldermalsen, M. (1975). Integrated control of apple pests in New Zealand. 1. Outline of experiment and general results. New Zealand Journal of Zoology 2 (1): 101-134.

Costello,M. and Altieri, M.A. (1995). Abundance, growth rate and parasitism of Brevicoryne brassicae and Myzus persicae (Homoptera: Aphididae). 
Agriculture, Ecosystems and Environment 52 (2-3): 187-196.

Cottrell T.E., Factors influencing dispersal of laraval Coleomegilla maculata from the weed Acalypha ostryaefolia to sweet corn, Entomol. Exp. APPL., 90, 313322 (1999).

Cowgill, S. (1990). The ecology of hoverflies on arable land. Game Conservancy Review 21: 70-71.Dangerfield, J.M.,McCarthy, T.S. and Ellery,W.N. (1998). The mound-building termite Macrotermes michaelseni as an ecosystem engineer. Journal of Tropical Ecology 14: 507-520.

Crawford HS and Jennings DT (1989) Predation by birds on spruce bud worm Choristoncura fumiferana: functional, numerical, and total responses. Ecology 70: 152-163.

Dahlste DL, Luck RF, Schlinger EI, Wenx JM and Copper WA (1977) Parasitoids and predators of the Douglas-fir tussock moth, Orgyia pscudotsugata (Lepidoptera: Lymantridae), in low to moderate populations in Central California. The Canadian Entomologist 109: 727-746.

Dent, D. (1995). Integrated Pest Management. CAB International. Wallingford, UK.

Dix ME (1990) Malachius ulkei Horn (Coleoptera: Malachiidaev. an egg predator of Paleacrita verna/a Peck (Lepidoptera: Geometridae). Journal of the Kansas Entomological Society 63(4): 648-652.

Dix ME (1991) Distribution of arthropod predators of insect pests in and near windbreaks. In: Garrett H. E. (ed.) Proceedings of the Second Conference on Agroforestry in North America. Springfield. Missouri, August 18-22. pp. 295-301.

Dix ME (1993) Conservation and enhancement of arthropod natural enemies of insect pests. Paper presented at the Symposium on Biological Control of forest Pests in the Great Plains; Status and Needs, conducted by Great Plains Agricultural Council, Forestry Committee's.

Dix ME and Donthiri S (1993) Opportunities for biological control of insect pests in agroforestry systems. In: Proceedings 1992 Society American Foresters National Convention [Richmond, Virginia, October 25-28, 1992], pp 278284.

Dix ME, Walla J, Harrell M, Klopfenstein Nand MacFall J (1993) Biological control of forest pests in the Great Plains: status, needs and issues. In: Proceedings of 44th Annual Meeting: Great Plains Agricultural Council Forestry Committee. Biological Control of forest Pests in the Great Plains: Status and Needs [July 13-16, 1992, Bismarck, North Dakota] 45: 44-52.

Dix, Johnson, Harrell, Case, Wright, Hodges, Brandle, Schoenberger, Sunderman, Fitzmaurice, Young and Hubbard in Agroforestry Systems 29 (1995) 311.

Dong, C.X. and Xu, C.E. (1984). Spiders in cotton fields and their protection and utilization. China Cotton 3: 45-47.

Eilenberg, J., Hajek, A. and Lomer, C. (2001). Suggestions for unifying the terminology in biological control. Biocontrol 46: 387-400. Abundance and efficiency of natural enemies of cereal aphids. Mitteilungen der Deutschen Gesellschaft fur Allgemeine und Angewandte Entomologie 3 (1-3): 312-315.

Forest Biological Control Task force [Bismarck, North Dakota, June 13-16, 1992], pp 72-76.

Frye RD, Dix ME and Carey DR (1988) Effects of two insecticides on abundance of insect families associated with Siberian elm windbreaks. Journal 
Kansas Entomological Society 61(3): 278-284.

Getz LL and Brighty E (1986) Potential effects of small mammals in highintensity agricultural systems in eastcentral Illinois. USA Agriculture, Ecosystems and Environment 15: 3950.

Hossain Z., Gurr G.M. and Wratten S.D., Habitat manipulation in Lucerne (Medicago sativa $\mathrm{L}$ ): Strips harvesting enhance biological control of insect pests, Int. J. Pest Mgmt., 47, 81-88 (2001).

JL (cd) Integrated Pest Management on Rangeland, pp 324-333. Westview Press, Boulder Nealis VG (1991) Natural enemies and forest pest management. The Forestry Chronicle 67: 500-505.

Johnson RJ and Beck MM (1988) Influences of shelterbelts on wildlife management and biology.

Johnson RJ, Brandle JR, Fitzmaurice RL and Poague KL (1993) Vertebrates for biological control of insects in agroforestry systems. Paper presented at the Symposium on Biological Control of Forest Pests in the Great Plains; Status and Needs, conducted by Great Plains Agricultural Council, Forestry Committee's Forest Biological Control Task Force [Bismarck, North Dakota, June 13-16, 1992], pp 77-84.

Katayama RW (1980) Seasonal abundance of insects in shelterbelts. $\mathrm{PhD}$ thesis. Department of Entomology, North Dakota State University, Fargo, NO, $216 \mathrm{pp}$.

Khan Z.R., Chiliswa P. and Hassanali A., Intercropping increase parasitism of pests, Nature, 338, 631-32 (1997).

Landis D.A., Wratten S.D. and Gurr G.M., Habitat management to conserve natural enemies of Arthropod pests in Agriculture, Апnu. Rev. Ent., 45, 175-
201 (2000).

Leius K (1967) Influence of wild flowers on parasitism of tent caterpillars and codling moth. Canadian Entomologist 99: 444-446.

Mason RR (1987) Nonoutbreak species of forest Lepidoptera. In: Barbosa $\mathrm{P}$ and Schultz JC (eds) Insect Outbreaks, pp 31-57. Academic Press, New York.

Mason RR (1992) Populations of arboreal spiders (Arancac) on Douglas-firs and true firs in the interior Northwest. Environmental Entomology 21: 75-89.

McEwen LC (1987) Function of insectivorous birds in a shortgrass IPM system. In: Capinera.

Menasch R.K., Local density responses of predatory insects of Helicoverpa species to a newly developed food supplement "Envirofeast" in commercial cotton in Australia, Int. J. Pest Mgmt., 43, 221-22 (1997)

Metcalf R.L. and Luckmann W.H., Introduction to Insect pest Management, 2nd edn., Wiley-Interscience publication, New York, 572 (1982).

PFRA, Prairie Farm Rehabilitation Administration (undated) Planting trees for wildlife. PFRA Shelterbelt Centre, Indian Head, Saskatchewan, Canada.

Ram P., Sharma S.S. and Saini R.K., Role of egg parasitism by Trichogramma chilonis (Ishii) to control Helicoverpa armigera (Hubner) in cotton-sesame intercropping, J. of Cotton Res. and Dev., 16, 109-110 (2002).

Ricchcrt SE and Lockley T (1984) Spiders as biological control agents. Annual Review Entomology 29: 299-320.

Roaeh SH and Thomas WM (1991) Overwintering and spring emergence of three coccinellid species in the Coastal Plain of South Carolina. Environmental Entomology 20(2): 540-544.

Ruppert V and Moltan J (1991) Augmentation of aphid antagonists by field margins 
rich in flowering plants. In: Polgar L, Chambers RJ, Dixon AFG and Hodck I (cds) Behavior and Impact of Aphidophaga, pp 243-247. SPB Academic Pub bv, The Hague. The Netherlands.

Shalaway SO (1985) Fenccrow management for nesting birds in Michigan. Wildlife Society Bulletin 13: 302-306.

Shanthakumari P., Biological Control of Crop Pests in India, Kalyani Publishers, New Delhi, 365 (2003).

Shi Z and Gao Z (1986) On the ecological efficiency of shcltcrbclt network and its yield increasing effect in paddy fields. Journal of Ecology 5(2): 10-14.

Stauffer OF and Best LB (1980) Habitat selection by birds of riparian communities: evaluating effects of habitat alterations. Journal of Wildlife Management 44: 1-15.

Steinberger Y, Aldon EF and Whitford WG (1991) Ground-dwelling arthropods of the Rio Puerco Watershed, New Mexico. Arid Soil Research and Rehabilitation 5: 147-153.

Stewart PA (1975) Cases of birds reducing or elim inating infestations of tobacco insects. Wilson Bulletin 87: 107-109.

Summers-Smith JO (1988) the Sparrows. T and AO Poyser. Calton, UK. 342 pp.

Suyin H (1959) the sparrow shall fall. New Yorker 35(34): 43-50 (10 Oct 1959).

Thomas E.D., Reichelderfer C.F. and Himpel
A.M., The effect of soil $\mathrm{PH}$ on the persistence of cabbage looper nuclear polyhedrosis virus in soil, $J$. Invertebrate Patho., 21, 21-25 (1973).

Thomas M.B., Sotherton N.W., Coombes D.S. and Wratten S.D., Habitat factors influencing the distribution of polyphagous predatory insects between field boundaries, Ann. Appl. Biol., 120, 197-202 (1992).

Torgersen TR and Mason RR (1987) Predation on egg masses 01 the Douglas-fir tussock moth (Lepidoptera: Lymantriidac). Env ironmental Entomology 16: 90-93.

Trnka P, Rozkosny R, Gaisler.l and Houskova L (1990) Importance of windbreaks for ecological diversity in agricultural landscape. Ekologia 9: 241-257.

Way M.I (1954) Studies on the association of the ant Oecophylla longinoda (Formicidac) with the scale insect Saissetra ranriburcnsis (Coccidac). Bulletin Entomology 5: 113-134.

Whelan CJ, Holmes RT and Smith HR (1989) Bird predation on gypsy moth (Lepidoptera: Lymantriidae) larvae: an aviary study. Environmental Entomology 18: 43-45.

Zhang Z (1992) the usc of beneficial birds for biological pest control in China. Biocontrol News and Information 13: IIN-16N.

\section{How to cite this article:}

Muneer Ahmad and Pathania, S.S. 2017. Ecological Engineering for Pest Management in Agro Ecosystem-A review. Int.J.Curr.Microbiol.App.Sci. 6(7): 1476-1485. doi: https://doi.org/10.20546/ijcmas.2017.607.176 